Зубенко В. В., аспірант *

Полтавська державна аграрна академія

\title{
ПРОДУКТИВНІСТЬ СВИНЕЙ ЗАЛЕЖНО ВІД ІНТЕНСИВНОСТІ РОСТУ КНУРІВ І СВИНОМАТОК У ПЕРІОД ВИРОЩУВАННЯ
}

\section{Рецензент - кандидат сільськогосподарських наук Л. Г. Перетятько}

\begin{abstract}
Наведно результати досліджень із вивчення продуктивності свиней великої білої породи залежно від гомо- $і$ гетерогенного поєднання кнурів та свиноматок різної інтенсивності росту в період їх вирошування Визначено, шо інтенсивне вирощування ремонтних свинок і кнуриів позитивно впливає на їх репродуктивні здатності та ріст $і$ збереження одержаного приплоду в підсисний період. Різниия між I і IV піддослідними групами складала 37,3 поросяти. Рекомендовано використовувати кнурів і свиноматок інтенсивного вирощування.
\end{abstract}

Ключові слова: велика біла порода, інтенсивне та екстенсивне вирощування, рецепрокне парування, репродуктивна здатність, підсисний період, СВК «Батьківщина».

Постановка проблеми. Як свідчить багаторічна практика та сучасні засоби масової інформації, одним із головних показників якості харчування людини є використання білку тваринного походження. За повідомленнями вітчизняних і зарубіжних авторів, цю проблему неможливо вирішити без інтенсивного ведення всіх галузей тваринництва, особливо, свинарства $[2,4,5]$. За офіційними даними зараз у світі із загального виробництва м'яса на частку свинини припадає близько $42 \%$ і в майбутньому іiі виробництво поступово буде нарощуватись $[1,3]$. До того ж ріст виробництва свинини буде здійснюватися за рахунок створення добре відселекційованих стад, цілеспрямованого вирощування молодняку, ефективного вибору і підбору батьківських пар та забезпечення оптимальних умов годівлі, а також утримання тварин усіх виробничих груп. Серед перерахованих факторів особливої уваги слід надавати вирощуванню і відбору кращих, більш інтенсивно ростучих ремонтних свинок і кнурців, так як через них можна ефективно впливати на якісне підвищення продуктивності стад, збільшення об'ємів виробництва свинини та покращання іiі економічних показників.

Аналіз останніх досліджень i публікацій, у яких започатковано розв'язання проблеми. За даними науковців та спеціалістів кращих гос- подарств, ремонтних свинок, а також кнурців доцільно вирощувати на рівні 550-600 г і більше середньодобових приростів. Свинок у перше парування доцільно допускати у 8-10-місячному віці при досягненні не менше 125 кг живої маси, а кнурців, відповідно, 135 кг [5]. На жаль, у багатьох господарствах на даний час поки ще досить мало приділяють уваги щодо вирощування ремонтного молодняку. Часто свинок для поповнення стада добирають безпосередньо 3 групи відгодівлі, що веде до зниження продуктивності стада та здорожчання виробленої продукції. Одночасно слід визнати, що в спеціальній літературі майже відсутні повідомлення про порівняльне вивчення продуктивності свиней та їх економічних показників залежно від інтенсивності, а також екстенсивності вирощування ремонтних свинок і кнурців.

Мета досліджень та методика їх проведення. Враховуючи актуальність та практичну значимость наведеного вище питання, метою наших досліджень передбачалося визначення впливу інтенсивності вирощування (регулюванням енергіï й протеїну в складі раціону) ремонтних свинок та кнурців на їх наступну продуктивність. Науково-господарські досліди було проведено на базі господарства СВК «Батьківщина» Котелевського району Полтавської області. Згідно 3 методикою, на основі попереднього вирощування молодняку, передбаченого першим етапом дослідження, було відібрано по 12 свинок інтенсивного росту (Інт.), які досягали 125 кг у середньому за 243 дні, й екстенсивного (Екс.) - за 422 дні, а також по 6 кнурців інтенсивного росту, які 135 кг досягали за 235 днів, і 6 голів екстенсивного росту - 387 днів. Залежно від рівня інтенсивності вирощування свинок і кнурців були проведені їх поєднання за методом рецепрокного парування. Поросних, а також підсисних маток i молодняк годували й утримували за технологією, прийнятою в господарстві.

Результати досліджень.

* Керівник-доктор сільськогосподарських наук, професор В. П. Рибалко 
СТОРІНКА МОЛОДОГО ВЧЕНОГО

\begin{tabular}{|c|c|c|c|c|}
\hline \multicolumn{5}{|c|}{ Показники продуктивності піддослідних свиноматок } \\
\hline \multirow[b]{2}{*}{ Показник } & \multicolumn{4}{|c|}{ Піддослідні групи } \\
\hline & 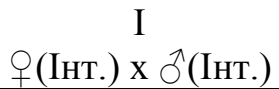 & $\begin{array}{c}\text { II } \\
q(\text { Інт. }) \times \overbrace{}^{\lambda} \text { (Екс.) }\end{array}$ & $\begin{array}{c}\text { III } \\
\left.q(\text { Екс. }) \text { x }{ }^{\Uparrow} \text { (Інт. }\right)\end{array}$ & $\begin{array}{c}\text { IV } \\
q(\text { Екс. }) \times{ }^{\Uparrow} \text { (Екс.) }\end{array}$ \\
\hline $\begin{array}{l}\text { Кількість маток } \\
\text { у групі, гол. }\end{array}$ & 12 & 12 & 12 & 12 \\
\hline $\begin{array}{l}\text { Кількість заплідне- } \\
\text { них маток, гол. }\end{array}$ & 11 & 10 & 10 & 9 \\
\hline $\begin{array}{c}\text { Кількість живих } \\
\text { поросят при } \\
\text { народженні, гол. }\end{array}$ & $10,8 \pm 0,35$ & $9,6 \pm 0,34$ & $9,0 \pm 0,21$ & $8,9 \pm 0,22$ \\
\hline Молочність, кг & $48,0 \pm 0,30$ & $47,5 \pm 0,55$ & $47,1 \pm 0,49$ & $46,5 \pm 0,62$ \\
\hline \begin{tabular}{|c|} 
Кількість відлучених \\
поросят на одну \\
матку, гол.
\end{tabular} & $9,2 \pm 0,21$ & $8,3 \pm 0,53$ & $7,5 \pm 0,59$ & $7,1 \pm 0,55$ \\
\hline \begin{tabular}{|c|} 
Маса гнізда поросят \\
у 2 міс., кг \\
\end{tabular} & $161,0 \pm 3,50$ & $136,9 \pm 8,74$ & $118,5 \pm 9,32$ & $107,9 \pm 8,36$ \\
\hline $\begin{array}{c}\text { Середня маса поросят } \\
\text { у } 2 \text { міс., кг }\end{array}$ & $17,5 \pm 0,52$ & $16,5 \pm 0,61$ & $15,8 \pm 0,42$ & $15,2 \pm 0,40$ \\
\hline $\begin{array}{c}\text { 3береженість поросят } \\
\text { за підсисний період, } \\
\%\end{array}$ & 85,18 & 86,45 & 83,33 & 79,77 \\
\hline
\end{tabular}

Як свідчать дані наведеної таблиці, багатоплідність піддослідних маток коливалися в межах 8,9-10,8 поросяти, кількість поросят відлучників - 7,1-9,2 голови, маса гнізда поросят у 2 місяці - 107,9-161,0 кг при збереження приплоду 79,77-85,18 відсотка. Найкращими показниками характеризувалися матки і кнури інтенсивного росту (I група), а найгіршими - екстенсивного (IV група). Тварини II і III піддослідних груп мали проміжні показники між аналогами IIV груп.

Таким чином, дані наших досліджень показали, що хоча після запліднення всі свиноматки

\section{БІБЛІОГРАФІЯ}

1. Акневский Ю. П. Влияние интенсивности роста на откормочные и мясные качества свиней разных генотипов / Ю. А. Акневский, Л. П. Гришина // Зб. «Свинарство». - № 55. - 2007. C. 25.

2. Березовський М. Д., Гетя А. А. Організація локальних систем виробництва свинини в Полтавській області / Полтава. - 2010. - Зб. «Свинарство». - С. 11-15. були поставлені в однакові умови годівлі й догляду, але ж показники їх продуктивності різко відрізнялися. Поросята свинок і кнурів інтенсивного рівня вирощування були більш активними, мали більшу живу масу і менший відхід, порівняно $з$ батьками екстенсивного рівня. Від маток I групи було отримано 101,2 поросяти, а від IV групи лише 63,9, або на 37,3 голови менше.

Висновок. Інтенсивне вирощування ремонтних свинок і кнурців позитивно впливає на їх репродуктивні здатності та ріст і збереження одержаного приплоду в підсисний період.

3. Лісний В. А. Структура собівартості свинини та оптимізація витрат при іiі виробництві / В. А. Лісний // Тваринництво сьогодні. - 2011. №5. - C. 26-30.

4. Мысик А. Т., Нетеса А. И. Свиноводство / М. : Колос, 1984. - $443 \mathrm{c}$.

5. Рибалко В. П., Мельник Ю. Ф., Нагаєвич В. М., Герасименко В. I. Породи свиней в Україні. - Х. : Еспада, 2001. - 80 c. 